\title{
An Interesting Study of Capacity Improvement of a Shipyard in Myanmar
}

\author{
Aung Ye Kyaw ${ }^{1}$, Djauhar Manfaat ${ }^{1}$, and Buana Ma'ruf ${ }^{2}$
}

\begin{abstract}
Six shipyards are in operation under control of Engineering Department of Inland Water Transport. Among them, Dalla shipyard currently accounts for about 50 percent of repair work on ships owned by the Inland Water Transport (IWT). The efficiency of the shipyard, which is about 164 years old, is hampered by old equipment, including some from the WWII-era (Word War II). Now the shipyard needs to be upgraded to improve its current capacity in ship repair. In this study, we proposed two ways which are supporting facilities and re-layout shipyard to increase ship repair. This paper obtains two alternative layouts of shipyard. The first alternative layout does not change the existing layout of shipyard but steel plate warehouse are built. The second alternative changes the existing layout because machine shop and steel plate warehouse is too far from the slipways. The first and second alternatives renovate zone 5 shop, carpenter shop, pipe and boiler shop and repair slipways. The two alternatives have steel plate warehouse as well as the addition of two material handling equipment mobile crane and forklift. The second alternative re-locates new machine shop near the slip ways for better material handling and time consuming. The second alternative is the best alternative in terms of economically feasible, good flow of material and perfect of technical term and the most number of ship repairs. Then it can be improved capacity amount 1.43 times and docking time can be reduced from average 33 days to 27 days.
\end{abstract}

Keywords—shipyard, capacity, ship repair, facility and relayout.

\section{INTRODUCTION}

Shipbuilding requires many workers having various skills (or trades), working within an established organizational structure at a specific location in which necessary facilities are available. The goal of a privately owned shipbuilding company is to earn a profit by building ships ${ }^{[1]}$. Shipbuilding industry in Myanmar has been developed by three sectors The first sector is the semi-government organization represented by Myanma Shipyard, which is engaged in shipbuilding and ship repair, together with other mechanical works on commercial basis The second sector is composed of shipyards owned by the government organizations such as IWT (Inland Water Transport), MPA (Myanma Port Authority, DMA (Department of Marine Administration) and so on, where their own ships and fleets are maintained. The last sector is private shipyards. There are large numbers of shipyards along the Yangon River and the Bago River as well as Seikgyi village near the Twan- Tay Canal.

There are 31 shipyards in Yangon region. State owned

\footnotetext{
${ }^{1}$ Aung Ye Kyaw and Djauhar Manfaat are with Department of Naval Architecture, Institut Teknologi Sepuluh Nopember, Surabaya, 60111, Indonesia.E-mail: aungyekyaw02@gmail.com; dmanfaat@na.its.ac.id.

${ }^{2}$ Prof. Buana Ma'ruf is with Department of Badan Pengkajian dan Penerapan Teknologi, UPT BPPT, Surabaya, 60111, Indonesia. E-mail: buanamaruf@yahoo.com.
}

shipyard is 9 and private owned shipyard is 22 . The most of state owned shipyard functions are to repair and maintain state owned ships. Dalla shipyard is one of the state own shipyard under Inland Water Transport. The functions of the shipyard are emergency docking for repair, major overhaul for engines, re-engineering, performing to support full utilization of fleet as planned and annual docking for repair and new constructions for privates and governmental departments. Most constructed ships are barges, tugs, self-propulsion barges and shallow draft vessels ${ }^{[2]}$. According to the Inland Water Transport Board Law in 2014, Inland Water Transport (IWT) may have to stand with own budgets and have to seek markets and customers themselves. Therefore, the shipyard needs to be upgraded to improve its current capacity in ship repair.

\section{METHOD}

This research uses the following steps:

a. To collect data and information from the shipyard. Most of the data usages obtain from observation and interviews with officer of Dalla shipyard and some missing data are from papers and books. Data collections have to support on improving and developing this research. Therefore, all data about collected directly from the shipyard.

b. To identify and define the problem. The identification of problem is a discussion that focuses on the development of Dalla shipyard. After the identification, the next choose the method or solve the problem. In this research the shipyard improve facilities, material handling equipment and re-layout. The alternative layout is determined by using DCF and NPV method.

c. To identify the alternative layout. Technical and economic terms evaluate for fist alternative and second alternative. Technical aspect also involves evaluation of the hardware and the software requirement of the proposed layout. Economic aspect involves cost and benefit associated with project layout.

d. To evaluate the alternative from economic side and technical side.

e. To choose a good alternative which it is can be increasing productivity, efficiency and good capacity. According to technical and economic feasibility calculations, the first alternative and the second alternative are feasible. But productivity of the first alternative is different as the second alternative. After comparing productivity of alternative, better productivity of alternative that is selected alternative. Methods of research can be seen in the flow chart outside diagram in figure 1 below: 


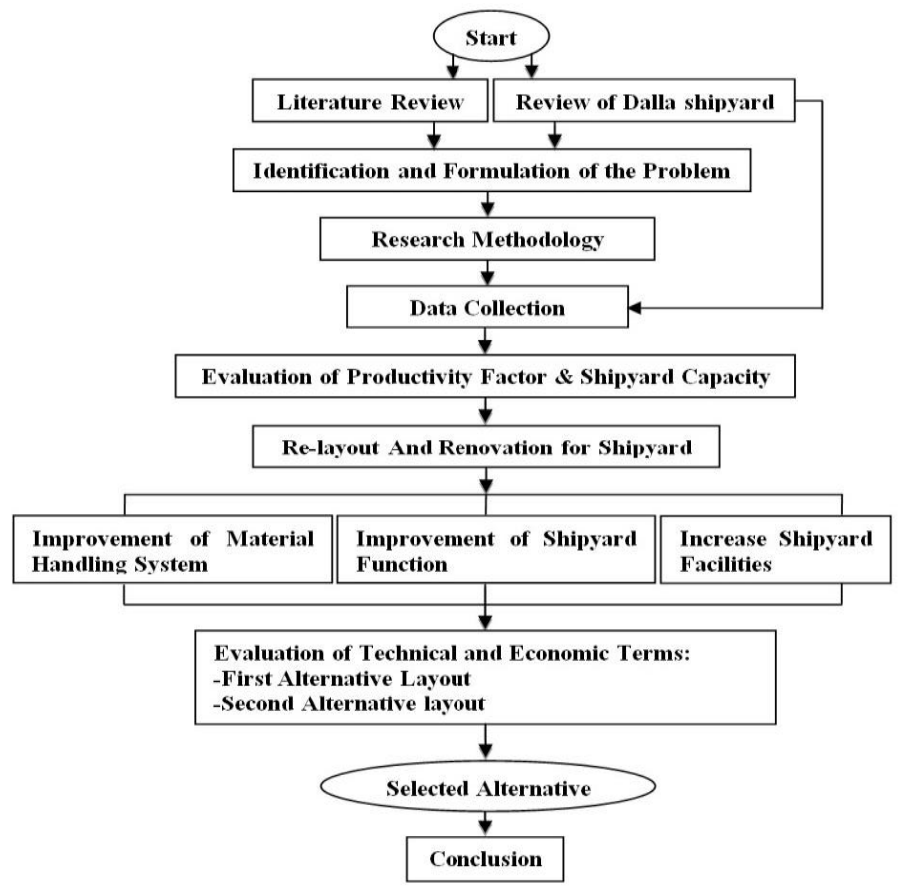

Figure 1. Research Flow Chart

\section{A. Shipyard Facility}

In general, shipyards have specialized workshops and spaces such as mechanical, electrical, steel sandblasting, docking, painting, and others. Electrical works, mechanical works, steel renewal, pipe work, and routine docking works such as washing, grit blasting, coating, sea chest cleaning, propeller dismantling, polishing, controlling on tail shaft and stern tube seals can be listed as the main facilities during a docking period ${ }^{[3]}$.

\section{B. Productivity}

Productivity implies a mental attitude that always has a view of the quality of life today should be better than yesterday and tomorrow better than today ${ }^{[4]}$. Quantitatively productivity is the ratio between the output and the input that is used per unit time (hour, day, month, and year). Productivity is commonly defined as a ratio between the output volume and the volume of inputs.

Productivity $=$ Output $/$ Input

\section{Time Series Analysis}

A time series is a collection of data recorded over a period of time-weekly, monthly, quarterly, or yearly. There are four components to a time series: the trend, the cyclical variation, the seasonal variation, and the irregular variation ${ }^{[5]}$.

$\mathrm{Y}=\mathrm{a}+\mathrm{bx}$

Where, $\mathrm{Y}=$ Demand (Unit)

$\mathrm{X}=$ the year of demand

$\mathrm{a}=$ the permanent component and demand every year

$\mathrm{b}=$ the quantity of demand in the first year

\section{Type of Layout}

Layout is defined as the arrangement of facilities aimed to achieve the operational objectives of an enterprise at minimum costs and with maximum efficiency. A poor layout can reveal highly detrimental to productivity and consequently to profitability ${ }^{[6]}$.

\section{E. Material Handling Equipment}

Materials handling is loading, moving and unloading of materials. To do it safely and economically, different types of tackles, gadgets and equipment are used. Materials handling is used with reference to industrial activity ${ }^{[7]}$.

\section{F. SWOT Analysis}

All organizations have strengths and weaknesses in the functional areas of business. The SWOT analysis is a business analysis technique that your organization can perform for each of its products, services, and market when deciding on the best way to achieve future growth. The process involves identifying the strength and weakness of the organization, and opportunities and threats present in the market that it operates in ${ }^{[8]}$. Internal Factor Evaluation (IFE) Matrix summarizes and evaluates the major strengths and weaknesses in the functional areas of a business, and it also provides a basis for identifying and evaluating relationships among those areas. Intuitive judgments are required in developing an IFE Matrix. An external factor evaluation (EFE) matrix allows strategists to summarize and evaluate economic, social, cultural, demographic, environmental, political, governmental, legal, technological, and competitive information.

\section{G. Net Present Value (NPV)}

Net Present Value is a central tool in discounted cash flow analysis, and is a standard method for using the time value of money to appraise long-term projects. Used for capital budgeting, and widely throughout economics, finance, and accounting, it measures the excess or shortfall of cash flows, in present value terms, once financing charges are met ${ }^{[9]}$. 
The NPV is calculated using the following formula:

$\mathrm{P}$ (i) $=\sum_{t=0}^{N} \frac{A_{t}}{(1+i)^{t}}$

Where,

$\mathrm{P}(\mathrm{i}) \quad=$ the present value of all cash flows at an interest rate $\mathrm{i} \%$

At $=$ cash flow at the end of the period

I = interest rate (Minimum Attractive Rate of

Return, MARR) or discount rate

$\mathrm{t}=$ the time of the cash flow

$\mathrm{N} \quad=$ number of period

H. Benefit- Cost Ratio (B/C ratio)

The $\mathrm{B} / \mathrm{C}$ ratio is designed to avoid the limitation of the NPV method. Thus, a project is evaluated in terms of benefits per one monetary unit of cost. A project would be worth investing in only if it meets the criterion where the $\mathrm{B} / \mathrm{C}$ ratio is greater than 1 . The $\mathrm{B} / \mathrm{C}$ ratio is calculated using the following formula:

Benefit-cost ratio $=($ benefit $) /($ cost $)$

Benefit-cost ratio $=\frac{\sum_{t=0}^{n} \frac{A_{t}}{(1+i)^{t}}}{\sum_{t=0}^{n} \frac{C_{t}}{(1+i)^{t}}}$

Where,

$\mathrm{Ct}=$ present value of cost or cost at time $\mathrm{t}$

\section{RESULTS AND DISCUSSION}

Competitiveness position of Dalla shipyard: The strategy-formulation tool summarizes and evaluates the major strengths or weaknesses and opportunities or threats in the functional areas of a business. The environment's characteristics of the middle-sized shipyards are the same; the proposed models may be considered as generic models not only for the Indonesian middle-sized shipyards but also for similar shipyards in other countries [10]. Therefore, all Strategic factors obtained from his research are used in this particular variable. The factors and the weight include as the table. The table 1 shows the result of SWOT matrix.

Forecast for future docking repair: Time series analysis method uses to analyze the future of shipyard increment. Previous data of ship repair for 5 years use to predict the future of ship repair for 5 years. According to data of ship repair from shipyard, the base year is 2011 year. To simplify the calculations, the years are replaced by coded values. That is, we let 2011 be 0,2012 be 1 , and so forth. The table 2 shows the docking repair in the shipyard during 5 years.

The shipyard can be repaired 58 vessels for 2016. Base on those five years ship repair data, we estimated ship repair of shipyard for 2020 . The calculations and data are same. The year 2017 is coded 6, 2018 is coded 7, 2019 is coded 8 and 2020 is coded 9 . The table 3 shows the forecast for the 5 years.

Estimation of Shipyard Capacity: The average docking repair per year is 70 vessels. The average docking day is 33 days. The average dwt is $268 \mathrm{dwt}$. The capacity of each slipway gets from calculation. The result of calculation is existing capacity of the shipyard.
TABLE1.

SWOT MATRIX OF THE SHIPYARD

\begin{tabular}{|l|l|l|}
\hline \multirow{4}{*}{ IFE Factor } & Strengths & Weakness \\
\cline { 2 - 3 } & 1. Location & 1. Company culture \\
\cline { 2 - 3 } & 2. Business network & 2. Delivery time \\
\cline { 2 - 3 } & 3. Price level & 3. Employee know-how \\
\cline { 2 - 3 } & 4. Quality of product & \\
\hline Opportunities & SO strategies & WO strategies \\
\hline 1. Domestic market & 1. Add facilities (S1,O1,O4) & $\begin{array}{l}\text { 1. Add material handling } \\
\text { equipment and re-layout } \\
\text { shipyard (w2, O1) }\end{array}$ \\
\hline 3. Quality of material & & \\
\hline 4. Bank support & & \\
\hline Threats & & \\
\hline 1. Quality of sub-contractor & & \\
\hline $\begin{array}{l}\text { 2. Govermment support to } \\
\text { shipyard }\end{array}$ & & \\
\hline $\begin{array}{l}\text { 3. Govermment support to } \\
\text { shipping }\end{array}$ & & \\
\hline 4. Price of material & & \\
\hline
\end{tabular}

TABLE 2.

THE DOCKING REPAIR IN THE SHIPYARD DURING 5 YEARS

\begin{tabular}{ccccc}
\hline Year & $\begin{array}{c}\text { Year of code } \\
(\mathrm{x})\end{array}$ & $\mathrm{y}$ & $\mathrm{x}^{2}$ & $\mathrm{xy}$ \\
\hline 2011 & 0 & 53 & 0 & 0 \\
2012 & 1 & 51 & 1 & 51 \\
2013 & 2 & 58 & 4 & 116 \\
2014 & 3 & 55 & 9 & 165 \\
2015 & 4 & 57 & 16 & 228 \\
Total & 10 & 274 & 30 & 560 \\
\hline \hline
\end{tabular}

TABLE 3.

THE FORECAST FOR THE 5 YEARS

\begin{tabular}{lc}
\hline \hline Year & Total vessels \\
\hline 2016 & 58 \\
2017 & 59 \\
2018 & 61 \\
2019 & 62 \\
2020 & 63 \\
\hline \hline
\end{tabular}

Re-layout Shipyard and Shipyard Facility: The conditions of Dalla shipyard that making some changes in order to rationalize the shipyard as follows: warehouse plate, re-layout shipyard and adding dock facilities. Relayout is changing the existing layout according to the current requirements. The layout may be re-designed to improve the existing layout or eliminate the inconvenience of the existing layout.

Purpose of the re-layout is to improve the productivity and efficiency of the shipyard. The existing shipyard layout has a lot of old facilities and lack of warehouses for storage of plates. The re-layout is also due to the preparation of the layout of the shipyard. The flow of materials fulfills reliably and can accelerate the process 
of repair work on this shipyard. Firstly, we try to change the existing layout of shipyard to improve capacity of shipyard. Dalla shipyard does not have steel plate warehouse until now. The shipyard cannot use foundry shop for a long time. Therefore, the first step proposes to use the foundry shop location for warehouse plate.

In the first alternative layout of the shipyard, there are new steel plate warehouse because the shipyard keep steel plate in ground. This warehouse can be stored 600 plates. The material handling equipment of a mobile crane (30 Ton) and a forklift (10 Ton) are additional for the first alternative layout. The road in the shipyard has already built concrete road. The road is $4 \mathrm{~m}$ widths. Therefore, the transportation of material is easy in the shipyard.

In the second alternative layout of the shipyard, there are new machine shop may be re-located near the slipways for better material handling and time consuming. . The machine shop is close the pipe and boiler. The size of machine shop is $1250 \mathrm{~m}^{2}$ (50 $\mathrm{m} \times 25$ $\mathrm{m})$ and the size of pipe and boiler shop is $900 \mathrm{~m}^{2}(45 \mathrm{~m} \mathrm{x}$ $20 \mathrm{~m}$ ). The machine shop is too big because it has many facility and equipment. But the workable machines in machine shop are 6 machines now. Therefore, the second alternative layout builds new machine shop between the pipe and boiler and power station shop for better material handling and time consuming. The size of machine shop in the second alternative is small because workable machine are re-installed in the new machine shop. The pipe and boiler shop in the second alternative layout is re-located for better material handling and time consuming. The size of pipe and boiler shop in the existing layout is too big because it gives piping and boiler repair service. But now the pipe and boiler shop give piping service only. Therefore, the size of the pipe and boiler shop in the second alternative layout is small. The second alternative layout renovates the store 1 for warehouse plate. slipways for better material handling and time consuming. Therefore, the first and the second alternative layout is the different layout.

Flow of Material: The layout problem is common to every type of enterprise - from the mall retailer to the largest manufacturing industries. The aim of each company is to obtain maximum benefit from their facilities. The adequacy of the layout directly affects the efficiency of the plant. Principal factors which affect shipyard layouts are briefly discussed. They are range of ship types to be built and number/year, space required and space available, amount of mechanization, material handling and construction methods employed.

Therefore, Criteria for the selection layout also refer to the Flow of Materials, using a new material handling equipment, material handling existing at this time. By determining the work time and required time, the rating time taken by the level of skill that is used $60 \%$ to $80 \%$ (the highest rating for the use of this type of equipment and manpower good skill level). The following table 4 and 5 show required time difference and total track difference.

Capacity Improvement: According to calculation of the total required time compare with the existing layout, the first alternative layout and the second alternative layout. Transportation times of the first alternative layout for machine shop and pipe shop is same as transportation times of the existing layout for which because the machine shop and pipe shop in the first alternative layout is not re-located. Transportation times of the second alternative for the machine shop and pipe shop is different as the others layout because the machine shop and pipe shop is re-located. The transportation time of the second alternative is the shortest of all.

TABLE 4.

COMPARISON OF REQUIRED TIME AT RATE OF SPEED 60\% TO $80 \%$

\begin{tabular}{llll}
\hline \hline No & Layout & Total Distance & Total Required Time \\
\hline 1 & Existing Layout & $2098 \mathrm{~m}$ & 293.04 minutes \\
2 & First Alternative Layout & $1948 \mathrm{~m}$ & 271.92 minutes \\
3 & Second Alternative Layout & $1540 \mathrm{~m}$ & 208.56 minutes \\
\hline \hline
\end{tabular}

TABLE 5.

COMPARISON OF REQUIRED TIME AT RATE OF SPEED $110 \%$ TO $120 \%$

\begin{tabular}{llll}
\hline \hline No & Layout & Total Distance & Total Required Time \\
\hline 1 & Existing Layout & $2098 \mathrm{~m}$ & 537.24 minutes \\
2 & First Alternative Layout & $1948 \mathrm{~m}$ & 498.52 minutes \\
3 & Second Alternative Layout & $1540 \mathrm{~m}$ & 382.36 minutes \\
\hline \hline
\end{tabular}

The number of existing material handling equipment in the shipyard is sufficient but the capacity of material handling is not sufficient. Therefore, the first and the second alternative layouts are additional of a new mobile crane (30 Ton) and a new forklift (10 Ton). The new hydraulic shearing machine is additional facilities because the existing hydraulic shearing machine is broken two years ago. The first and the second alternative layout is the same material handling equipment and facilities. But the second alternative relocates machine shop and pipe and boiler shop near the of the second layout from average docking time (27 days) are 83 vessels. The forecast vessel is 58 vessels based on forecast calculation. To improve productivity the ship repair must work overtime above calculation. The rate of growth docking ship repair and maintenance is $70 / 58=1.2$ times. When compared with the result of docking (27 days), the rate of growth docking ship repair and maintenance is $83 / 58=1.43$ times. The forecast vessel 58 is the next year target vessel number. After reducing the docking times from 33 to 27, the rate of growth docking ship repair and maintenance is from 1.2 
times to 1.43 times. The following table shows the ship repair number for the existing, the first and the second layout. The table 6 shows the ship repair number for the existing, the first and the second layout.
The following table 8 shows the Discounted Cash Flow (DCF) and Net Present Value (NPF) for the second alternative layout. The table 9 shows the Payback period, Net Present Value and Cumulative Present Value.

TABLE 6.

SHIP REPAIR FOR THE EXISTING, THE FIRST AND THE SECOND LAYOUTS

\begin{tabular}{llll}
\hline \hline No & Layout & Number of vessels & Rate of Docking \\
\hline 1 & Existing layout & 70 vessels & 1.2 times \\
2 & First Alternative layout & 72 vessels & 1.24 times \\
3 & Second Alternative layout & 83 vessels & 1.43 times \\
\hline \hline
\end{tabular}

Investment Calculations for Shipyard Layout: The first and second alternative layouts add renovation of buildings procurement of equipment and supporting facilities. The following table 7 shows List of Facilities and Equipment for Second Alternative Layout.

\section{CONCLUSION}

Based on the problems, objectives and discussion of the problem will be able to be concluded as follows:

a. Total weight score of IFE is 2.73 above 2.5 indicated that the company has a strong internal

TABLE 7.

LIST OF FACILITIES AND EQUIPMENT FOR SECOND ALTERNATIVE LAYOUT

\begin{tabular}{ccc}
\hline No & Shipyard Facilities & Cost (Kyats) \\
1 & Building cost for Machine shop & 90 million \\
2 & Building cost for Pipe and boiler shop & 90 million \\
3 & Renovation cost for Warehouse plate & 30 million \\
4 & Renovation cost for Carpenter shop & 20 million \\
5 & Renovation cost for Zone 5 & 30 million \\
6 & Renovation cost for slipways no 1 and 14 & 30 million \\
No & Material Handling Equipment & 66 million \\
1 & Forklift Truck (10 Ton) & 121 million \\
2 & Mobile Crane (30 Ton) & 21.411 million \\
No & Machine & 548.9 million \\
1
\end{tabular}

Economic feasibility helps shipyard assess the viability, cost, and benefits associated with projects before financial resources are allocated. It helps decision to determine the positive economic benefits to the organization that the proposed layout will provide, and helps quantify the problem. For second alternative layout, the initial investment of shipyard is Myanmar Kyat K. 548.99 million. Shipyard applies 50\% (discount rate $12 \%$ ) of investment for loan from bank and $50 \%$ (discount rate 14\%) of investment is its capital money.

After calculation of Discounted Cash Flow (DCF), the results show the payback period and benefit cost ratio. The payback period is 2019 and benefit/cost ratio is 1.13 . The benefit/cost ratio is greater than 1 . Therefore, the layout is advantageous for shipyard. Positive cumulative present value is $\mathrm{K}$. 74,726,771. The feasibility of the proposed layout generated economic benefits.

The second alternative layout is good organized. The flow of material is good than the first alternative. Therefore, second alternative layout is eliminating damage or excessive movements. According to calculations by the method of Discount Cash Flow (DCF) and Net Present Value (NPV) with system payback period, the second alternative is also feasible for Dalla shipyard project.

The revenue is the same amount for the first and the second alternative layouts. The revenue is based on ship repair forecasting for (2016-2020). But the cost is different for the first and the second alternative layouts.

The first alternative layout is lower than the second alternative because second alternative layout has new building for machine shop and piping shop. osition. Total weight score of EFE is 2.59 above 2.5 indicated that the company has a high response to its external business environment. According to IFE and EFE, the shipyard faces strong business position in the market.

b. The first alternative layout have new steel plate warehouse, renovation for machine shop, carpenter shop, Zone 5 shop, pipe and boiler shop and slipways repair. The second alternative layout have new steel plate warehouse, new machine shop, new pipe and boiler shop, renovation for carpenter shop, zone 5 shop and slipways repair.

c. The first and the second alternative layout have the same material handling equipment and facilities. The additional facilities and equipment for the first and the second alternative are a mobile crane, a forklift and hydraulic shearing machine. But the layout of the first alternative is the different layout of the second alternative. Therefore, the first alternative for ( 31 days) is 72 vessels and the second alternative for ( 27 days) is 83 vessels. The rate of growth docking ship repair and maintenance is 1.43 times. After reducing the docking times from 33 days to 27 days, the rate of growth docking ship repair and maintenance is from 1.2 times to 1.43 time.

d. Ship repair forecasting based on actual data is the future ship repair capacity.

e. Re-layout is one of the best methods in the shipbuilding industry through re-alignment shipbuilding, renovations, additions material handling equipment. 
August $2^{\text {nd }}$ 2016, Postgraduate Program Institut Teknologi Sepuluh Nopember, Surabaya, Indonesia

f. Based on the feasibility study using Discount Cash Flow NPV (Net Present Value) with System Payback Period in which the proportion of loans with $50 \%$ (interest rate of $12 \%$ ), and its own capital of $50 \%$ ( $14 \%$ interest), and an investment of $\mathrm{K}$ 548.9 million for the layout alternative second, then the result of the calculation using the cost of these investments project viable and feasible, due to the return of capital are in 4 th year.

\section{REFERENCES}

[1] Storch, R.L (1995). "Ship Production". The Society Naval Architects and Marine Engineers

[2] Than, C (2009). Myanmar Shipbuilding, Naval Architects and Marine Engineers. https://spruz.academia.edu/CharlieThan.

[3] Celik, Metin. "Fuzzy Axiomatic Design-based Performance Evaluation Model for Docking Facilities in Shipbuilding Industry”. Applications 36:599-615, 2009.
[4] Rafiy, Muhammad. "Study of Improvement Fishermen Welfare Through Improved Productivity And Model Development In The Costal North Konawa", The International Journal of Engineering And Science (IJES), Vol 4, Issue 12: 62-67, 2015.

[5] Chiang, C Y (2014). An empirically-simulated investigation of the impact of demand forecasting on the bullwhip effect: Evidence from U.S. auto industry, [Online] Available: www.sciencedirect.com

[6] Chabane, Hamid. "Design of Small Shipyard Facility Layout Optimized for Production and Repair". Symposium International Journal, [Online] Available: http//www.metratech.net/spip.

[7] Ray, Siddhartha (2008). Introduction to Material Handling, National institute of Technical Teachers' Training and Research.

[8] David, F. R. Strategic Management Concepts and Cases, (15th ed.) 2015, Prentice Hall, New York

[9] Chaiwat, P (2012). Economic Feasibility Evaluation of Government Investment Project by Using Cost Benefit Analysis: A Case Study of Domestic Port Port A), Laem-Chabang Port Chonburi Province. Available online at www.sciencedirect.com

[10] Ma'ruf, Buana (2006). Environmental-Based Strategic Management Model for Indonesia's Medium-Sized Shipyards, Published in The Journal of Ship Production, Vol. 22, No. 4 November.

TABLE 8.

the Discounted Cash Flow (DCF) ANd Net PRESEnt Value (NPF)

\begin{tabular}{|l|r|r|r|r|r|r|}
\hline Description & 0 & 1 & 2 & 3 & 4 & 5 \\
\hline Investment & $548,900,000$ & & & & & \\
\hline Revenue Statement+ & & $290,000,000$ & $295,000,000$ & $305,000,000$ & $310,000,000$ & $315,000,000$ \\
\hline Another income (5\% FS) + & & $14,500,000$ & $14,750,000$ & $15,250,000$ & $15,500,000$ & $15,750,000$ \\
\hline Total Revenue Statement & & $304,500,000$ & $309,750,000$ & $320,250,000$ & $325,500,000$ & $330,750,000$ \\
\hline Miscellaneous expenses (3\%)- & & $9,135,000$ & $9,292,500$ & $9,607,500$ & $9,765,000$ & $9,922,500$ \\
\hline Operating costs (10\% TRS) - & & $30,450,000.0$ & $30,975,000.0$ & $32,025,000.0$ & $32,550,000.0$ & $33,075,000.0$ \\
\hline Net revenue (Netto)= & & $(264,915,000)$ & $(269,482,500)$ & $(278,617,500)$ & $(283,185,000)$ & $(287,752,500)$ \\
\hline Tax 25\%- & $(66,228,750)$ & $(67,370,625)$ & $(69,654,375)$ & $(70,796,250)$ & $(71,938,125)$ \\
\hline Cash Flow After Taxes & & $198,686,250$ & $202,111,875$ & $208,963,125$ & $212,388,750$ & $215,814,375$ \\
\hline Discount rate (12\%) & & 1.12 & 1.25 & 1.4 & 1.57 & 1.76 \\
\hline Discounted Cash Flow (DCF) & & $177,398,438$ & $161,689,500$ & $149,259,375$ & $135,279,459$ & $122,621,804$ \\
\hline Total & $548,900,000$ & $177,398,438$ & $339,087,938$ & $488,347,313$ & $623,626,771$ & $746,248,575$ \\
\hline Net Present Value & & $(371,501,563)$ & $(209,812,063)$ & $(60,552,688)$ & $74,726,771$ & $197,348,575$ \\
\hline Criteria (Min 0) & & & & & & \\
\hline Internal Rate of Return (IRR) & & & & & & \\
\hline Criteria (Min 8\%) & $25 \%$ & & & & & \\
\hline Benefit cost Ratio & & & & & & \\
\hline
\end{tabular}

TABLE 9.

Payback PeRIOd, Net Present VAlue and Cumulative Present Value

\begin{tabular}{cccc}
\hline \hline Year & Cash Flow & Present Value & Cumulative Present Value \\
\hline & $548,900,000$ & & \\
2016 & $198,686,250$ & $177,398,438$ & $-371,501,563$ \\
2017 & $202,111,875$ & $161,689,500$ & $-209,812,063$ \\
2018 & $208,963,125$ & $149,259,375$ & $-60,552,688$ \\
$\mathbf{2 0 1 9}$ & $\mathbf{2 1 2 , 3 8 8 , 7 5 0}$ & $\mathbf{1 3 5 , 2 7 9 , 4 5 9}$ & $\mathbf{7 4 , 7 2 6 , 7 7 1}$ \\
2020 & $215,814,375$ & $122,621,804$ & $197,348,575$ \\
\hline \hline
\end{tabular}

